Selcuk Journal of Agriculture and Food Sciences

http://sjafs.selcuk.edu.tr/sjafs/index

Research Article

\section{SJAFS}

(2020) 34 (2), 141-147

e-ISSN: $2458-8377$

DOI:10.15316/SJAFS.2020.208

\title{
Evaluation of Losses in Cherry Production: A Case Study of Izmir*
}

\author{
(D)Meltem KANTAROĞLU ${ }^{1}$, (D) Nevin DEMIRBAŞ, \\ ${ }^{1}$ Ege University, Institute of Science, Department of Agricultural Economics, İzmir, Turkey \\ ${ }^{2}$ Ege University, Faculty of Agriculture, Department of Agricultural Economics, İzmir, Turkey
}

\begin{tabular}{l}
\hline ARTICLE INFO \\
\hline Article history: \\
Received date: 27.04 .2020 \\
Accepted date: 20.05 .2020 \\
\hline Edited by: \\
Zuhal KARAKAYACI; Selçuk Universi- \\
ty, Turkey \\
Reviewed by: \\
Ahmet KUBAŞ; Tekirdağ Namık Kemal \\
University, Turkey \\
Özge Can NiYAZ; Çanakkale Onsekiz \\
Mart University, Turkey \\
\hline
\end{tabular}

Keywords:

Cherry

Fruit / Product Losses

Kemalpaşa

İzmir

\begin{abstract}
The purpose of this research is to evaluate the causes of losses in cherry orchards. The research was carried out in Kemalpaşa district of İzmir province, which was an important cherry production center. An approach has been followed to evaluate the losses in cherry production both technically and economically. For this purpose, face-to-face surveys were conducted with 102 cherry producers and the data of the research were obtained from these surveys. The 5-point Likert scale was used in determining the participation of the producers in the judgments about losses in cherry production. The reliability of the data obtained with the Likert scale was tested with the Cronbach Alpha coefficient. Kruskal-Wallis test was used to determine whether there is a difference between the groups for continuous variables that do not have normal distribution. For discrete variables, whether there is a statistical difference between the characteristics of producers and enterprises and losses was determined by ChiSquare Analysis (Independence Test).

According to the research results, producers' views on losses in cherry production focus on seasonal factors and incorrect cultural practices at different stages of production. On the other hand, the opinions received from the producers for the solution of the current problems were mostly focused on training studies and labor costs. Adequate and inefficient producer organization in the region also adversely affects the technical and economic aspects of production. It is anticipated that the technical and economic information flow required by the producers will increase with the activation of the organization and thus will create positive results on the losses.
\end{abstract}

\section{Introduction}

Quantity and/or quality losses in the supply chain of food produced for human nutrition are defined as food loss (FAO 2013). Food loss can occur from the farm to fork along the supply chain. The main stages in which food losses occur; pre-harvest and post-harvest applications in fruit orchards and storage, processing, distribution and final consumption stages (Gustavsson et al. 2011; Demirbaş et al. 2017; Demirbaş 2018). Losses occur at every stage of the supply chain for different reasons. In developed countries, food losses are mostly seen at the retail and consumption stages (Permanandh 2011; Prusky 2011; EB 2014). Over 95\% of food losses in developing countries are unintentionally lost in the early stages of the food supply chain (FAO 2018). The food losses in Turkey usually occur in agricultural production stage (Tatlidil et al. 2013).

\footnotetext{
* Corresponding author email: nevin.demirbas@ege.edu.tr *This article was derived from the first author's Master Thesis
}

One of the most important subsector of the agricultural sector is the fresh fruit and vegetable sector. Produced fresh fruits and vegetables are spoiled and discarded for various reasons until they reach the consumer and this situation changes according to the types and varieties. In general, it is stated that $4-12 \%$ of the losses in fresh fruits and vegetables are in production, 2$8 \%$ of the products are transferred to the market and wholesaler, $1-5 \%$ are in the consumption phase (Tatlıdil et al. 2013; Ünlü 2015). These losses occurring at different stages along the supply chain can increase up to $50-60 \%$ depending on the product.

Losses of fruit in Turkey, is said to be up $12.7 \%$ of the total fruit production (Ozturk et al. 2012). In developed countries, there are studies stating that these losses are around 5\% (Kader 2005). The main causes of losses in fruit production; misapplications during production, deficiencies and mistakes in the fight against diseases and pests, lack of proper techniques during harvesting and ignorance of necessary practices can be listed (Food Drink Europe 2013; Keding et al. 2013; Dijksma 2015; FAO 2018; Tarabay et al. 2018; TR Ministry of Foreign Affairs 2019). For example, inade- 
quate water and food management can lead to decreased production quality and high losses. Adverse weather conditions such as heavy rain can also result in high levels of illness (Thompson 2007). In addition, fruits can remain in the tree because they do not meet the quality standards (shape, size, weight) set by processors, retailers or the target market (Stuart 2009).

Cherry is a type of stone fruit that has a considerable sales potential and superior aroma in the world due to its ability to grow in various ecologies. Cherry is more susceptible to physiological and pathological disorders during storage and shelf life, and its storage life is shorter than soft seed fruit species (Çetin 2010; Hasdemir 2011). Physiological and pathological disorders cause post-harvest quality losses. Cracking and pitting, wrinkling and blackening of stalk color are the most important physiological disorders in cherry. Physiological and pathological disorders cause post-harvest quality losses. Cracking and pitting, wrinkling and blackening of stalk color are the most important physiological disorders in cherry (Mitcham et al. 2006). Stalk darkening is a big negativity for the producer in terms of marketing (Schick et al. 2000).

One of the main problems of cherry growing is that regular yields cannot be obtained from the trees every year. Fruit set and flowering are the most important problems. Fertilization is another problem. Another factor affecting the low yield is climate conditions (Lang 2019). The warm winter months cause the flowering time to be delayed, the flowering period to be prolonged and the flowering to be irregular in cherry trees that cannot realize winter rest (Engin and Akçal 2013). In addition, the pollination process may fail due to bad weather or cause color fading due to nutritional deficiencies (Creamer and Johnson 2018). Another important factor in terms of losses in cherry is marketing strategies. For cherry, like other fruit types, harvest time is extremely important in terms of storage and marketing (Crisosto et al. 2003).

The aim of this research is to evaluate the losses in cherry production with the information obtained from the producers. Therefore, this research was held in Kemalpaşa district which is one of Turkey's most important production centers.

\section{Materials and Methods}

\subsection{Methods of sampling and data collection}

All of the cherry producers included in the Farmer Registration System (FRS) of Kemalpaşa district of İzmir constituted the main population of the research. In the preliminary study, it was determined that the number of cherry producers registered in FRS was 2190 as of 2019 (Ministry of Agriculture and Forestry, 2019). Proportional sampling formula was used to determine the number of producers to be surveyed (Güneş and Arıkan 1988; Newbold 1995).

$$
n=\frac{N p(1-p)}{(N-1) \sigma_{p x}{ }^{2}+p(1-p)}
$$

In the formula;

$\mathrm{n}=$ Sample size

$\mathrm{N}=$ Total number of producers (2190)

$\mathrm{p}=$ Proportion of producers who have lost production

$\sigma \mathrm{p} \times 2=$ Variance of the ratio

In order to reach the maximum sample size, the proportion of producers who lost production phase was taken as p: 0.50 and (1-p): 0.50. With this approach, sample size was determined as 102 with $95 \%$ significance level and $9.5 \%$ margin of error.

The research area consists of the Merkez, Ören, Bağyurdu, Yiğitler and Armutlu villages of Kemalpaşa district where cherry production is intense. Information was also obtained from Kemalpaşa Agriculture and Forestry District Directorate and Chamber of Agriculture for the selection of the villages. The number of producers interviewed in each determined village was found by considering the contribution of the villages to the total number of producers. The number of producers in the research area is $50.41 \%$ of the total number of cherry producers in Kemalpaşa. The number of questionnaires per village was determined by converting them into integers (Table 1).

Table 1

Number of producers surveyed by villages (2019)

\begin{tabular}{lccc}
\hline Villages & $\begin{array}{c}\text { Number of } \\
\text { Producers }\end{array}$ & $\begin{array}{c}\text { Proportional } \\
\text { Contribution } \\
\text { of Villages } \\
(\%)\end{array}$ & $\begin{array}{c}\text { Number of } \\
\text { producers } \\
\text { surveyed }\end{array}$ \\
\hline Bağyurdu & 294 & 27 & 28 \\
Ören & 265 & 24 & 25 \\
Armutlu & 251 & 23 & 23 \\
Merkez & 170 & 15 & 15 \\
Yiğitler & 124 & 11 & 11 \\
Total & 1.104 & 100 & 102 \\
\hline
\end{tabular}

\subsection{Methods of data analysis}

In the research, the 5-point Likert attitude scale was used to compile the opinions of the producers about cherry production and the losses that occurred (Tavşancil 2014). The scale is based on the principle of determining the positive, negative or neutral participation status of the participants in each of the expressions in the item set created to measure a certain structure (Bora and Altunışık 2016). Weighted average method was used to determine the order of importance of the statements directed to the producers (Kalayc1 2008). The Cronbach Alpha coefficient was calculated to test the reliability of the data obtained with the Likert scale. Reliability Analysis, it is an indicator of how reliable any measurement tool measures the feature (Tavşancil 2014). The coefficient (Cronbach) that takes a value between 0 and 1 is called the Alpha coefficient (Cronbach 1951; Kalayc1 2008). Cronbach Alfa is expressed as follows:
$0<\mathrm{R} 2<0.40$
unreliable,
$0.40<\mathrm{R} 2<0.60$
low reliability,
$0.60<\mathrm{R} 2<0.80$
very reliable, 
$0.80<\mathrm{R} 2<1.00 \quad$ high reliability.

In this study, Cronbach Alpha coefficient was calculated as $(0.875)$. The result is an indication that the scale is highly reliable.

Since the variables did not show normal distribution, the Kruskal-Wallis test was used to determine whether there are differences between groups for continuous variables. Whether there is a relationship between the groups of variables for discrete variables was demonstrated with the Chi-square (Independence) test (Newbold 1995; Kalayc1 2008).

\section{Results and Discussion}

Table 2

General characteristics of cherry producers in terms of enterprise size (year)

\begin{tabular}{|c|c|c|c|c|c|}
\hline Enterprise Size (da) & $\begin{array}{c}\text { Number of Enterpri- } \\
\text { se }\end{array}$ & Age & Education & $\begin{array}{l}\text { Variables } \\
\text { Agricultural Experien- } \\
\text { ce }^{*}\end{array}$ & $\begin{array}{c}\text { Experience in cherry } \\
\text { production* }\end{array}$ \\
\hline Group 1: $\leq 10$ & 28 & 48.85 & 8.85 & 16.89 & 16.10 \\
\hline Group 2: $11 \leq 29$ & 44 & 48.50 & 8.50 & 20.93 & 18.97 \\
\hline Group $3: 30 \leq 49$ & 17 & 51.44 & 7.38 & 22.38 & 20.88 \\
\hline Group 4: $\geq 50$ & 13 & 51.33 & 8.91 & 25.66 & 22.33 \\
\hline Overall Average & & 49.45 & 8.45 & 20.63 & 18.92 \\
\hline Total & 102 & & & & \\
\hline P Value & & - & - & 0.041 & 0.049 \\
\hline
\end{tabular}

*According to Kruskal Wallis test, the difference between the groups is significant for $\mathrm{p}<0.05$.

\subsection{Participation of producers to agricultural organi- zations}

Increasing the organizational awareness and level of the producers, determining the appropriate agricultural policies, making the production planned, supporting the enterprises financially and technically and increasing the bargaining power of the producers are extremely important (Karlık 2010). Although the level of organization of the producers within the scope of the research is low, it is determined that they are generally registered to more than one agricultural organization. The agricultural institutions that the producers are registered with are the Chamber of Agriculture (36.51\%), the Agricultural Sales Cooperative (23.81\%), the Agricultural Credit Cooperative (20.11\%), the Irrigation Cooperative (15.87\%) and the Agricultural Development Cooperative (3.70\%) (Table 3).

Table 3

Agricultural organizations in which producers are registered

\begin{tabular}{lcc}
\hline Agricultural organizations & Number & $\%$ \\
\hline Chamber of Agriculture & 69 & 36.51 \\
Agricultural Sales Cooperative & 45 & 23.81 \\
Agricultural Credit Cooperative & 38 & 20.11 \\
Irrigation Cooperative & 30 & 15.87 \\
Agricultural Development Coope- & 7 & 3.70 \\
rative & $189^{*}$ & 100.00 \\
Total &
\end{tabular}

*Since it is a member of more than one organization, the total is different.

\subsection{Demographic characteristics of producers}

The average age of the producers is 49.45 years, and the training period is 8.45 years. There is no statistically difference between the group averages for both variables. The average experience of the producers in the agricultural sector is 20.63 years, and the duration of experience in cherry production is 18.92 years. There is statistically difference between the group means ( $\mathrm{p}$ $<0.05)$. When the distribution of the general characteristics of the producers by the enterprise groups, it was found that the experience in the agricultural sector and the experience in cherry production were highest in the fourth group (Table 2).

\subsection{Loss rates in the enterprises}

In the questionnaires conducted with the producers, it was first asked whether there was any loss in the production of cherries. It was determined that more than $3 / 4$ of the producers $(77.50 \%)$ experienced different rates of loss in production. The proportion of those who have almost no losses in cherry production is around $23 \%$. Then, the producers were asked at which stage of agricultural production and at what rate they lost. The answers given are grouped according to their loss rates. It was determined that $86.49 \%$ of the producers in the first group $(\leq 5 \%)$ experienced cherry losses at the most production stage. In general, it was determined that $63.25 \%$ of the producers experienced the loss of cherries at the highest production stage (Table 4) 
Table 4

Loss levels in the enterprises by production stages

\begin{tabular}{|c|c|c|c|c|c|c|c|c|}
\hline \multirow[t]{2}{*}{$\begin{array}{l}\text { Lost Rate Groups } \\
(\%)\end{array}$} & \multicolumn{2}{|c|}{ Preharvest } & \multicolumn{2}{|c|}{ Harvest } & \multicolumn{2}{|c|}{$\begin{array}{l}\text { Transport and Stora- } \\
\text { ge (on farm) }\end{array}$} & \multicolumn{2}{|c|}{$\begin{array}{c}\text { Processing and Pac- } \\
\text { kaging } \\
\text { (on farm) }\end{array}$} \\
\hline & Number & $\%$ & Number & $\%$ & Number & $\%$ & Number & $\%$ \\
\hline Group 1: $\leq 5$ & 64 & 86.49 & 28 & 84.85 & 2 & 40.00 & 3 & 60.00 \\
\hline Group 2: 6-15 & 4 & 5.40 & 2 & 6.06 & 2 & 40.00 & 1 & 20.00 \\
\hline Group 3:16-21 & 5 & 6.75 & 3 & 9.09 & 1 & 20.00 & 1 & 20.00 \\
\hline General $^{*}$ & 73 & 63.25 & 33 & 28.21 & 5 & 4.27 & 5 & 4.27 \\
\hline
\end{tabular}

*Multiple answers were received.

\subsection{Production technique preferences of the producers}

Fruit production in Turkey, it can be done with different production techniques such as conventional agriculture, ecological agriculture and Good Agricultural Practices (GAP). The application of certified production techniques such as ecological agriculture and GAP is important for possible product losses. As a matter of fact, according to the Chi_Square analysis conducted for this purpose, a statistically significant difference was found between the groups regarding loss rates and making certified production (Table 5). At all levels of loss, it is observed that those who make conventional production experience more losses than those who prefer the production technique that requires certification. Certified production in only $22.55 \%$ of the examined enterprises is an important finding in terms of losses.

Table 5

Comparison of certified production preference and the loss rates in the enterprises surveyed

\begin{tabular}{llllll}
\hline \multirow{2}{*}{ Certified Production } & \multicolumn{3}{c}{ Lost Rate Groups $\%$} & \multicolumn{2}{c}{ Chi-Square } \\
\cline { 2 - 6 } & $0 \leq 5$ & $6-15$ & $16-20$ & Value & $\mathrm{p}^{*}$ \\
\hline Yes & 17 & 2 & 3 & \multirow{2}{*}{3.151} & \multirow{2}{*}{0.037} \\
No & 52 & 3 & 2 & & \\
\hline "Significant for $\mathrm{p}<0.05$ & & & & &
\end{tabular}

\subsection{Comparison of the production amounts and the loss rates}

The average age of cherry orchards is 19.81 years. As a result of the Chi-Square analysis conducted to test the assumption that the amount of cherry production may affect losses, a statistically significant difference was found between the cherry production amounts and the loss rate groups (Table 6). The most frequent loss rate is $0 \leq 5 \%$.

Table 6

Comparison of the cherry production amounts and the loss rates

\begin{tabular}{lccccc}
\hline $\begin{array}{l}\text { Cherry production } \\
\text { amounts (ton) }\end{array}$ & \multicolumn{3}{c}{ Lost Rate Groups $(\%)$} & \multicolumn{2}{c}{ Chi-Square } \\
\hline Groups & $\leq 5$ & $6-15$ & $16-20$ & Value & $\mathrm{p}^{*}$ \\
\hline Group 1: $20 \geq$ & 24 & 1 & 1 & & \\
Group 2: $21-29$ & 39 & 3 & 2 & 3.58 & 0.048 \\
Group 3: $30 \leq$ & 6 & 1 & 2 & & \\
\hline "Significant for $\mathrm{p}<0.05$ & & & & &
\end{tabular}

\subsection{Causes of the product losses}

Cherry losses mostly occur in the period preharvest in the studied enterprises. Producers have stated seasonal factors $(43.10 \%)$ as the most important reason for losses in cherry production. This is followed by diseases and pests (14.70\%), worker errors (9.80\%), inability to determine appropriate rootstocks (4.90\%), loss of spilled fruit $(2.90 \%)$ and lack of cold storage $(2.00 \%)$. The rate of those who do not know the cause of the loss is at an important level of $22.50 \%$ (Table 7).

Table 7

Producers' opinions on the causes of loss

\begin{tabular}{lcc}
\hline Reasons & Number & $\%$ \\
\hline Seasonal Factors & 44 & 43.10 \\
Do Not Know the Cause of the Loss & 23 & 22.50 \\
Diseases and Pests & 15 & 14.70 \\
Worker Errors & 10 & 9.80 \\
Inability to Determine Appropriate & 5 & 4.90 \\
Rootstocks & 3 & 2.90 \\
Loss of Spilled Fruit & 2 & 2.00 \\
Lack of Cold Storage & 102 & 100.00 \\
Total &
\end{tabular}

3.7 Technical and economic risk sources in cherry production

The technical and economic risk sources faced by the producers in cherry production have been evaluated in detail as they directly affect the product losses. According to this, the most important technical risk sources were low yield (4.82) due to diseases and pests and frost (4.82)(Table8).

Table 8

Technical risk sources in cherry production

\begin{tabular}{|c|c|c|c|c|c|c|c|}
\hline Technical risks & 1 & 2 & 3 & 4 & 5 & $\begin{array}{l}\text { Likert } \\
\text { Scale } \\
\text { Mean } \\
*\end{array}$ & $\begin{array}{l}\text { Standard } \\
\text { Deviation }\end{array}$ \\
\hline $\begin{array}{l}\text { Low Yield Due to } \\
\text { Diseases and Pests }\end{array}$ & - & - & - & 18 & 84 & 4.82 & 0.383 \\
\hline Frost & - & - & - & 18 & 84 & 4.82 & 0.383 \\
\hline $\begin{array}{l}\text { Selection of } \\
\text { Spraying Time }\end{array}$ & 1 & 1 & - & 37 & 63 & 4.57 & 0.652 \\
\hline Pruning Time & 2 & 2 & 1 & 47 & 50 & 4.38 & 0.784 \\
\hline Soil Selection & 2 & 4 & - & 47 & 49 & 4.34 & 0.838 \\
\hline Land Location & 1 & 6 & 3 & 41 & 51 & 4.32 & 0.869 \\
\hline $\begin{array}{l}\text { Insufficiency of } \\
\text { Irrigation Water }\end{array}$ & 1 & 14 & 1 & 34 & 52 & 4.20 & 1.062 \\
\hline $\begin{array}{l}\text { Rainfall is More } \\
\text { Than Needed }\end{array}$ & - & 2 & 1 & 23 & 75 & 4.17 & 4.819 \\
\hline
\end{tabular}


Table 8 (Continuation)

Technical risk sources in cherry production

\begin{tabular}{lccccccc}
\hline $\begin{array}{l}\text { Rootstock Selec- } \\
\text { tion }\end{array}$ & 4 & 15 & 5 & 53 & 25 & 3.78 & 1.095 \\
$\begin{array}{l}\text { Less Precipitation } \\
\text { Variety Selection }\end{array}$ & 5 & 27 & 6 & 23 & 43 & 3.75 & 1.325 \\
$\begin{array}{l}\text { Product Damage } \\
\text { Due to Flood }\end{array}$ & 26 & 25 & 3 & 10 & 38 & 3.09 & 1.695 \\
\hline $\begin{array}{l}* 1=\text { Strongly Disagree, } 2 \text { = Disagree, } 3=\text { Undecided, 4 = Agree, } 5= \\
\text { Strongly Agree }\end{array}$
\end{tabular}

These results show that producers face problems in taking necessary technical measures against climatic Table 9

Economic risk sources in cherry production

\begin{tabular}{|c|c|c|c|c|c|c|c|}
\hline Economic risks & 1 & 2 & 3 & 4 & 5 & Likert Scale Mean $^{*}$ & Standard Deviation \\
\hline High and Constantly Increasing Input Costs & - & - & - & 3 & 99 & 4.97 & 0.169 \\
\hline High Irrigation Water Cost & - & - & - & 8 & 94 & 4.92 & 0.270 \\
\hline Fluctuations in Product Prices & - & - & - & 20 & 82 & 4.80 & 0.398 \\
\hline Fluctuations in Export & 1 & - & 1 & 37 & 63 & 4.58 & 0.620 \\
\hline High Loan Interest Rates & 3 & 13 & 2 & 19 & 65 & 4.27 & 1.170 \\
\hline Problems in Obtaining Experienced and Skilled Workers & 14 & 21 & - & 18 & 49 & 3.66 & 1.563 \\
\hline Insufficient Family Workforce & 16 & 28 & 1 & 14 & 43 & 3.39 & 1.611 \\
\hline Difficulties in Finding Markets & 34 & 17 & 1 & 17 & 33 & 2.98 & 1.729 \\
\hline
\end{tabular}

*1 = Strongly Disagree, 2 = Disagree, 3 = Undecided, 4 = Agree, 5 = Strongly Agree

\section{Results and Discussion}

It has been determined that the producers experienced the most product loss in the pre-harvest period. Most of the factors affecting cherry losses are related to the growing period and cultural measures. Adverse weather conditions such as heavy rain and frost, as a result of which high levels of disease and pest (insect) invasions are shown as the most important causes of loss.

The reasons for the loss in the harvest period may be due to the wrong harvesting techniques due to the workers, the lack of cold storage for summer fruits such as cherries in the region and the fact that the harvest time could not be determined correctly. The establishment of a net system in the gardens may be one of the most important solution suggestions for producers who experience quality and product losses due to seasonal factors (Doğan 2016; Creamer and Johnson 2018; Özdemir Çifçi and Demirbaş 2020). It is envisaged that the methods of pest control applied at the right time and effectively can prevent product losses due to diseases and pests. In order to prevent all these factors mentioned above and the loss of products that may occur as a result of these, producers should be encouraged to switch to certified production methods such as GAP. It is stated that the application of techniques such as GAP, Integrated Struggle with Pests and Integrated Product Growing in production will have a preventive and reducing effect on losses (Demirbaş 2019). Again, according to the results of the analysis, it has been determined that certified producers such as GAP, Organic agriculture experience less losses compared to conventional producers. Mandatory processes such as traceability and supervision can be directly effective in conditions. Some of these problems arise from insufficient knowledge and experience, while others are due to economic factors. Indeed, the most important of the economic risk sources (Table 9) faced by the producers in production is the high and constantly increasing input costs (4.97). This is followed by the high irrigation water cost (4.92). In particular, problems in obtaining experienced and skilled workers for harvest constitute an important risk source for losses. reducing the causes of loss. Training processes, which are an integral part of GAPs, also have a positive effect in terms of reducing losses (SKD 2018).

According to research findings, losses due to diseases and pests and seasonal factors are higher than losses due to lack of cold storage. The same results have been achieved in another study involving the same area of research (Bayraktar 2015). Producers can find solutions to these problems by getting help from Provincial and District Agricultural and Forestry Directorates regarding the technical problems in cherry production. The District Agriculture and Forestry Directorate can contribute to the awareness of the producers by organizing seminars or training meetings on cherry production and providing practical training in the gardens (Başkaya 2011).

It has been determined that the producer organization in the research region is not sufficient. Increasing agricultural production and obtaining quality products depend on the efficient organization of producers. It is stated by the producers that the agricultural chamber does not play an active role in the region. Another important problem is that the Cherry Producers Union, which was operating in the past in the region, does not exist today. With the re-establishment of Cherry Producers Union, technical and financial support will be provided to producers on issues such as production techniques, harvesting, storage and packaging.

\section{References}

Başkaya Z (2011). Türkiye'de kiraz tarımının coğrafi esaslar1. Doğu Coğrafya Dergisi 16(26):26-45.

Bayraktar ÖV (2015). İzmir Kemalpaşa yöresinde GlobalGAP uygulayan ve uygulamayan kiraz iş- 
letmelerinin teknik ve ekonomik yönünün sürdürülebilir tarım açısından değerlendirilmesi. Doktora Tezi, Ege Üniversitesi Fen Bilimler Enstitüsü (Basılmamış), İzmir.

Bora SB, Altunışık R (2016). Pazarlama araştırmalarında Likert tipi ölçeklerin özelliklerinin cevaplama tarzları üzerindeki etkilerinin incelenmesi, Bartın Üniversitesi İI.B.F. Dergisi 7(14): 577- 598.

Creamer N, Johnson LK (2018) Introducing FarmLevel Loss into the Food Waste Discussion. Huffington Post. 04.

Crisosto CH, Crisosto GM, Metheney P (2003). Consumer acceptance of "Brooks" and "Bing" cherries is mainly dependent on fruit SSC and visual skin color. Postharvest Biology and Technology 28 (2003): 159- 167.

Cronbach LJ (1951). Coefficent alpha and the internal structure of tests, Psichometrika Journal,16 (3): 297-334.

Çetin T (2010). Uluborlu ilçesinde kiraz tarımı, Atatürk Üniversitesi Doğu Coğrafya Dergisi 15(23):185220.

Demirbaş N (2018). Dünya'da ve Türkiye'de gıda israfını önleme çalışmalarının değerlendirilmesi. IBANESS Kongreler Serisi, 21-22 Nisan, PlovdivBulgaristan, s.521-526.

Demirbaş N (2019). İyi tarım uygulamaları ile meyve bahçelerinde ortaya çıkan üretim, hasat ve hasat sonrası kayıpları azaltılabilir mi? IBANESS Kongreler Serisi, Plovdiv- Bulgaristan, 20-21 Nisan, s. 289-296.

Demirbaş N, Niyaz ÖC, Apaydın YM (2017). An evaluation on problems within food supply chain in Turkey in terms of food losses and waste. International Balkan and Near Eastern Social Sciences Conference Series, March 4-5, Edirne-Turkey, pp.830-835.

Dijksma S (2015). No More Food to Waste, Global Action to Stop Food Losses and Food Waste, Netherlands.

Doğan B (2016). Kırsal kalkınma yatırımlarının desteklenmesi programı kapsamında kiraz işletmelerinin yatırımlardan yararlanma düzeyi ve işletmelerin yatırım eğilimlerinin belirlenmesi: Kemalpaşa ilçesi örneği. Yüksek Lisans Tezi, Ege Üniversitesi Fen Bilimleri Enstitüsü (Basılmamış), İzmir.

EB (2014). Dünya Bankası: Gıda fiyatlarında düşüş yaşanmakla beraber gıda kayıp ve israfi gıda arz güvenliğini tehdit ediyor. http://blog.ibp.gov.tr/ Erisim tarihi: 15 Şubat 2019.

Engin H, Akçal A (2013). Kiraz Yetiştiriciliği. Çanakkale 18 Mart Üniversitesi Ziraat Fakültesi Yayınlar1, 1.Baskı, Çanakkale, 133s.

FAO (2013). Report of the Expert Consultation Meeting on Food Losses and Waste Reduction in the Near East Region: Towards a Regional Comprehensive Strategy. Egypt, 33p.
FAO (2018). Save Food: Global: Global Initiative on Food Loss and Waste Reduction.http: www.fao.org/savefood/tr/. Erișim tarihi: 04 Ocak 2020.

Food Drink Europe ( 2013). Every Crumbs Counts Joint Food Wastage Declaration,http://everycrumbcounts.eu/uploads/static_pag es_documents/Joint_Declaration/www.fao.org/save food/tr/. Erişim tarihi: 04 Ocak 2020.

Gustavsson J, Cedeberg C, Sonesson U, Otterdijk RV, Meybeck A (2011). Global Food Losses and Food Waste: Extend, Causes and Prevention, FAO, Rome.

Güneş T, Arıkan R (1988). Tarım Ekonomisi İstatistiği, Ankara Üniversitesi Ziraat Fakültesi Yayınları. Yayın No: 1049, Ankara Üniversitesi Basımevi, Ankara.

Hasdemir M (2011). Kiraz yetiştiriciliğinde iyi tarım uygulamalarının benimsenmesini etkileyen faktörlerin analizi. Doktora Tezi, Ankara Üniversitesi Fen Bilimleri Enstitüsü (Basılmamış), Ankara.

Kader AA (2005). Increasing Food Availability by Reducing Postharvest Losses of Fresh Produce. http://ucce.ucdavis.edu/files/datastore/234-528.pdf (Erișim tarihi: 12 Aralık 2018).

Kalaycı Ö (2008). SPSS Uygulamalı Çok Değişkenli İstatistik Teknikleri, ISBN: 9799759091148, Ankara.

Karlık Aİ (2010). Türkiye'de ve Avrupa Birliğinde tarımsal örgütlenme modelleri. Yüksek Lisans Tezi, İnönü Üniversitesi Sosyal Bilimler Enstitüsü (Basılmamış), Malatya.

Keding GB, Schneider K, Jordan I (2013). Production and processing of foods as core aspects of nutritionsensitive agriculture and sustainable diets. Food Security 5 (6): 825-846.

Lang GA (2019). Achieving sustainable cultivation of temperate zone tree fruits and berries Volume 2: Case studies, Burleigh Dodds Science Publishing, Cambridge, UK, (ISBN: 978178676212 2; www.bdspublishing.com).

Ministry of Agriculture and Forestry (2019). Çiftçi Kayıt Sistemi Verileri. Kemalpaşa İlçe Tarım ve Orman Müdürlüğü, Kemalpaşa-İzmir.

Mitcham EJ, Crisosto CH, Kader AA (2006). Recommendations for Maintaining Postharvest QualitySweet Cherry. http://postharvest,ucdavis.edu.Produce/ProduceFact s/Fruits/cherry.shtml (Erişim tarihi: 01 Şubat 2019).

Newbold P (1995). Statistics for Business and Economics. Prentice Hall International Editions.

Özdemir Çiftçi R, Demirbaş N (2020). Meyve ve sebze üretiminde ortaya çıkan kayıplar üzerinde etkili olan faktörler: İzmir İli örneği. Mediterranean Agricultural Sciences 33(1): 85-91.

Öztürk FP, Karamürsel D, Sarısı HC, Emre M, Kaçal E, Eren İ, Çalhan Ö (2012). 0900 kiraz çeşidinde 
hasat ve hasat öncesi kayipların belirlenmesi. $V$. Bahçe Ürünlerinde Muhafaza ve Pazarlama Semроzуити, 18-21 Eylül, İzmir, s.171-179.

Permanandh J (2011). Factors affecting food security and contribution of modern Technologies in food sustainability. Journal of the Science of Food and Agriculture 91(15):2707-2714.

Prusky D (2011). Reduction of the incidence of postharvest quality losses, and future prospects. Food Security 3(4):463-474.

Schick JL, Toivonen P.A (2000). Optimizing Cherry Stem http://postharvest.tfrec.wsu.edu/pages/PC2000Q (Erişim tarihi: 1 Şubat 2019).

SKD (2018). Sürdürülebilir Tarım İlkeleri İyi Uygulamalar Rehberi. http://www.skdturkiye.org/files/yayin/surdurulebilir -tarim-ilkeleri-iyi-uygulamalar-rehberi_4.pdf (Erişim tarihi: 11 Aralık 2019).

Stuart T (2009). Waste: Uncovering the Global Food Scandal.

https://www.telegraph.co.uk/culture/books/bookrev iews/5842301/Waste-Uncovering-the-Global-FoodScandal-by-Tristram-Stuart-review.html (Erişim tarihi : 7 Şubat 2019).
Tarabay PA, Chahine-Tsouvalakisb H, Tawkc ST, Nemera N, Habiba W (2018). Reduction of food losses in Lebanese apple through good harvesting and postharvest practices. Annals of Agricultural Sciences 63 (2018) 207-213.

Tatlıdil FF, Dellal İ, Bayramoğlu Z (2013). Food Losses and Waste in Turkey. FAO, 67p.

Tavşancıl E (2014). Tutumların Ölçülmesi ve SPSS ile Veri Analizi, Nobel Yayınları, Ankara, ISBN: 978605-133-740-1.

Thompson AK (2007). Preharvest Factors on Postharvest Life. https://pub.epsilon.slu.se/9029/1/Ali_L_120906.pdf (Erişim tarihi: 09 Şubat 2019).

TR Ministry of Foreign Affairs (2019). Bazı Meyveler İçin Hasat Sonrası Kayıpların Ekonomik Analiz Raporu.

http://www.postharvestproject.com/uploads/outputs /d3270dfd-9d15-4b65-a2b9-9d13567be7e9.PDF (Erişim tarihi: 12 Aralık 2019).

Ünlü M (2015). Yaş Meyve ve Sebzelerde Derim (Hasat) Sonrası Oluşan Kayıplar ve Çözüm Önerileri. Tarımsal Araştırmalar ve Politikalar Genel Müdürlüğü, Alata Bahçe Kültürleri Araştırma Enstitüsü, Mersin. 